\title{
Metabolic changes in human bronchial epithelial cells upon chronic exposure to hexavalent chromium
}

\author{
Leonardo MR Ferreira ${ }^{1,2^{*}}$, Maria S Santos ${ }^{1,3}$, M Carmen Alpoim ${ }^{1,3,4}$, Ana M Urbano $1,2,4$ \\ From 16th International Charles Heidelberger Symposium on Cancer Research \\ Coimbra, Portugal. 26-28 September 2010
}

Some hexavalent chromium [Cr(VI)] compounds are well established occupational respiratory tract carcinogens. However, despite a very large number of studies, the mechanisms of $\mathrm{Cr}(\mathrm{VI})$-induced malignization at the cellular and molecular levels are only now beginning to be understood with more detail. It has been known for decades, since the seminal studies of Otto Warburg in the $1920 \mathrm{~s}$, that most solid tumors exhibit a specific metabolic pattern, characterized by a strong contribution of lactic fermentation to the overall ATP production, even in the presence of ample oxygen. This particular metabolic reprogramming, known as the Warburg effect, provides the background for several diagnosis and therapeutic approaches, such as PET (positron emission tomography) and the design of inhibitors of glycolytic enzymes, respectively. Nevertheless, the exact role of the Warburg effect in carcinogenesis and, in particular, in $\mathrm{Cr}(\mathrm{VI})$-induced lung cancer, remains elusive. In this study, the gradual changes in energy metabolism occurring during the chronic exposure of human bronchial epithelial cells, the main targets of $\mathrm{Cr}(\mathrm{VI})$-induced carcinogenicity, to subcytotoxic or mildly cytotoxic concentrations of $\mathrm{Cr}(\mathrm{VI})$ were assessed using markers of bioenergetic status, such as glucose uptake, lactate production and adenylate energy charge. Significant changes were observed in all parameters, in a time- and dosedependent manner, compatible with a role of the energy metabolism in the $\mathrm{Cr}(\mathrm{VI})$-induced malignization process.

\section{Acknowledgements}

This work was partly funded by a CIMAGO grant (CIMAGO 26/07).

\footnotetext{
* Correspondence: leonardo_m_r_ferreira@yahoo.com

'Departamento de Ciências da Vida, Faculdade de Ciências e Tecnologia,

Universidade de Coimbra, Coimbra, Portugal

Full list of author information is available at the end of the article
}

\section{Author details}

'Departamento de Ciências da Vida, Faculdade de Ciências e Tecnologia, Universidade de Coimbra, Coimbra, Portugal. ${ }^{2}$ Unidade de Química-Física Molecular, Faculdade de Ciências e Tecnologia, Universidade de Coimbra, Coimbra, Portugal. ${ }^{3}$ Centro de Neurociências e Biologia Celular, Coimbra, Portugal. ${ }^{4}$ Centro de Investigação em Meio Ambiente, Genética e Oncobiologia (CIMAGO), Faculdade de Medicina, Universidade de Coimbra, Coimbra, Portugal.

Published: 24 September 2010

doi:

Cite this article as: Ferreira et al: Metabolic changes in human bronchial epithelial cells upon chronic exposure to hexavalent chromium. BMC Proceedings 2010 4(Suppl 2):P16.
Submit your next manuscript to BioMed Central and take full advantage of:

- Convenient online submission

- Thorough peer review

- No space constraints or color figure charges

- Immediate publication on acceptance

- Inclusion in PubMed, CAS, Scopus and Google Scholar

- Research which is freely available for redistribution

Submit your manuscript at www.biomedcentral.com/submit
C Biomed Central 